\title{
PENGARUH PEMBERIAN JUS DAUN SIRIH ( Piper betle L.) TERHADAP UJI ORGANOLEPTIK DAN MIKROBIOLOGI DENDENG DAGING AYAM
}

\author{
(EFFECT OF GOOD LEAF LEAVES (Piper betle L.) ON ORGANOLEPTIC TEST AND \\ MICROBIOLOGY OF CHICKEN) \\ Salma Warni ${ }^{1}$, Cut Aida Fitri ${ }^{1}$, Dzarnisa ${ }^{*}$ \\ ${ }^{1}$ Program Studi Peternakan, Fakultas Pertanian, Universitas Syiah Kuala
}

\begin{abstract}
Abstrak. Dendeng adalah olahan curing dengan memotong dalam bentuk lembaran tipis dan dikering secara tradisional yang merupakan hasil proses pengeringan dan, kemudian diberi garam dapur, bumbu rempah-rempah serta gula, seperti ketumbar, bawang merah, bawang putih, dan jahe hasil olahan merupakan hasil proses curing dan pengeringan dengan memotong dalam bentuk lembaran tipis dendeng yang beredar di pasaran kebanyakan mengandung kadar gula 20-52\%, kadar lemak 1,0-17,4\%, kadar garam 0,4-0,6\%, serat kasar 0,4-15,5\% dan $a_{w} 0,4-0,5$. Pengawetan salah satu cara daging agar dapat disimpan dalam jangka waktu yang lama.

Dendeng tergolong bahan makanan semi basah yaitu bahan pangan yang mempunyai kadar air tidak terlalu tinggi dan tidak terlalu rendah, yaitu antara 15-50\%. Daging direndam jus daun sirih $(0,10,15,20$,$) kemudian diolah menjadi dendeng. Variabel yang diukur meliputi warna, aroma, rasa,$ keempukan. Rancangan penelitian yang digunakan adalah Rancangan Acak Lengkap 4x5 dan dilanjut dengan uji mikrobiologi. Hasil menujukan bahwa semakin tinggi konsentrasi jus daun sirih berpengaruh nyata $(<0,05)$ terhadap warna, rasa, aroma, keempukan.

presentase jus daun sirih berpengaruh sangat nyata $(<0,01)$ terhadap total mikroba dendeng daging ayam dengan pemberian jus daun sirih. Daging ayam menujukan batasan cemaran bakteri lebih tinggi dari ketetepan SNI yaitu $1,10 \times 10^{5} \mathrm{CFU} /$ gram, sedangkan menurut SNI batasan cemaran maksimum cemaran mikroba dalam pangan yaitu $1 \times 10^{5} \mathrm{CFU} /$ gram.
\end{abstract}

Kata kunci : Dendeng, daging ayam, Daun sirih, ,Total mikroba

Abstract. Dendeng is traditionally processed dried produce which is the result of drying process and curing by cutting in the form of thin slices of jerky on the market mostly contain $20-52 \%$ sugar content, $0.4-0.6 \%$ salt content, fat content $1.0-17.4 \%$, crude fiber $0.4-15.5 \%$ and aw $0.4-0.5$. one way of preserving meat to be stored for long periods of time. Fillet is classified as semi-saturated food that is food that has water content is not too hig, which is between $15-50 \%$. Meat soaked betel leaf juice $(0$, $10,15,20$,) then processed into jerky. The variables measured include color, aroma, taste, tenderness. The research design used was Completely Randomizedt Designt 4x5 continued with microbiology test. The results showed that the higher concentration of betel leafl juice significantly $(<0.05)$ to the color, flavor, aroma, tenderness. The percentage of betel leaf juice had a very significant effect $(<0,01)$ on total of chicken jerky microbial with betel leaf juice. Chicken meat pointed to the limits of bacterial contamination higher than ketetepan SNI that is $1.10 \times 105 \mathrm{CFU} /$ gram, whereas according to SNI limit maximum contamination of microbial contamination in food that is $1 \mathrm{x} 105 \mathrm{CFU} / \mathrm{gram}$.

Keywords: Chiken meat, Betle leaf, Dendeng, Micrbiologi

\section{PENDAHULUAN}

Dendeng adalah hasil olahan curing dengan memotong dalam bentuk lembaran tipis dan dikering secara tradisional yang merupakan hasil proses pengeringan dan, kemudian diberi garam dapur, garam sendawa, bumbu rempah-rempah serta gula, seperti ketumbar, bawang merah, bawang putih, dan jahe (Bintoro et al., 2008). Makanan bentuk semi basah merupakan dendeng bahan yang biasanya terbuat dari daging dan ikan, berbentuk tipis dan lebar, dibumbui dan dikeringkan. Dendeng dapat dimakan tanpa rehidrasi dan tidak memberikan rasa kering pada produk. Dendeng ayam adalah jenis makanan awetan yang dibuat dengan cara pengeringan dengan menambah garam, gula, dan bahan lain untuk memperoleh rasa yang diinginkan (Esti dan Sediadi, 2000). Dendeng tergolong bahan makanan semi basah yaitu bahan pangan yang mempunyai kadar air tidak terlalu tinggi dan 
tidak terlalu rendah, yaitu antara 15-50\% (Legowo et al., 2002). Produk pangan hewani, termasuk didalamnya merupakan daging salah satu komonitas pangan dapat diolah untuk mencukupi protein kebutuhan tubuh .Tetapi, bahan tersebut juga sangat mudah mengalami kerusakan karena perubahan kimiawi ataupun aktivitas mikroba. Perlu dilakukan upaya pengolahan untuk mengawetkan daging sehingga memiliki umur simpan yang lebih panjang, menghindari ketengikan dan meningkatkan citarasa.

\section{METODE PENELITIAN}

Penelitian ini melakukan Laboratorium Pengolahan Daging dengan Ikan di Jurusan Peternakan Fakultas Pertanian Universitas Syiah Kuala Darussalam Banda Aceh. Penelitian ini dilaksanakan dari bulan November 2017 sampai dengan Januari 2018.

\section{Uji Organoleptik}

\section{MATERI DAN METODE}

Panelis peyang memberikan penelaian organoleptik warna, aroma, rasa, keempukan terhadap dendengg daging ayam sebanyak 20 panelis dengan 2 kali ulangan.

\section{Metode Penelitian}

Pengunakan bahan dalam menelitian digunakan adalah daging broiler tanpa tulang dan jus daun sirih (Piper betle L). Bumbu-bumbu yang megunakan, bawang putih, bawang merah, gula merah, , cabe merah, ketumbar, lengkuas, garam dapur, asam jawa dan minyak goreng.

\section{Prosedur Penelitian}

Sebelum melakukan penelitian terlebih dahulu daging ayam dibersihkan dengan menggunakan air bersih agar kualitas daging tetep terjaga dan memisah tulang dan kulit dengan daging ayam. Setelah daging bersih, daging ayam diiris-iris tipis, kemudian daging diberi garam sebanyak 15 gram untuk 300 gram daging. Kermudian direndam dalam jus daun sirih daging ayam sesuai dengan perlakuan yaitu $0 \%$ (kontrol), 10\%, 15\%, dan 20\% selama 12 jam dalam masing-masing baskom. Daging dikeringkan dengan panas sinar matahari selama 3 hari sampai kering dan kandungan airnya $10 \%$.

\section{Uji Mikrobiologi dendeng daging ayam}

Total mikroba dendeng dihitung menggunakan metode plate count. Sampel sebanyak 1 gram ditimbang, lalu dilakukan pengeceran dimulai dengan pengenceran $10^{-1}$ sampai pengenceran $10^{-5}$. Kemudian dari $10^{-5}$ diambil $1 \mathrm{ml}$ diinokulasi pada media PCA. Diinkubasi cawan petri di dalam inkubator lama 48 jam dan suhu $37^{\circ} \mathrm{C}$ didalam keadaan balik guna hindari tetesan air. Jumlah media mikroba yang tumbuh dihitung digunakan colony counter. Koloni mikroba dendeng dihitung dalam $\log \mathrm{cfu} / \mathrm{g}$ dengan menggunakan rumus.

$$
\text { CFU/gram }=\text { Jumlah koloni } x=\frac{1}{\text { Pengeceran }}
$$




\section{Analisa Data}

Data dianalisa penelitian dapat diperoleh dengan menggunakan Analisis Sidik Ragam (Analysis of Varian/ANOVA). Apabila terdapat pengaruh terhadapn perlakuan, maka akan meanjutkan Uji BTN (Beda Nyata Terkecil) (Stell dan Torrie, 1993).

\section{HASIL DAN PEMBAHASAN}

Penelitian yang dilakukan terhadap dendeng daging ayam jus daun sirih, diperoleh 4 sampel merupakan suatu cara untuk mengukur,menguji atau menilai mutu produk dengan menggunakan kepekaan alat indera manusia seperti mata, hidung, mulut dan ujung jari tangan. Uji organoleptik ini mengugunakan uji peringkat (rangking) yaitu membandingkan beberapa sampel antar perlakuan. Sampel disajikan dengan menggunakan angka secara ananimus terhadap panelis supaya tidak mempengaruhi respon panelis. Jumlah 60 sampel nilai uji organoleptik dendeng daging ayam dengan pemberian persentase jus daun sirih (Piper betle L) yang berbeda didapat dari uji organoleptik panelis. Uji organoleptik yang dilakukan meliputi uji warna, aroma, rasa dan keempukan.

\section{Uji Organoleptik}

Hasil pengujian terlihat pada Warna, Aroma, Rasa, Keempukan dari dendeng daging ayam dengan pemberian jus daun sirih.

Tabel 1. Rataan Nilai Uji Organoleptik Dendeng Daging Ayam dengan Penambahan Jus Daun Sirih (Piper betle L.)

\begin{tabular}{ccccc}
\hline \multirow{2}{*}{ Kriteria } & \multicolumn{5}{c}{ Jus Daun Sirih } \\
\cline { 2 - 5 } & $0 \%$ & $10 \%$ & $15 \%$ & $20 \%$ \\
\hline Warna & 2,95 & 3,10 & 3,10 & 3,20 \\
Aroma & 3,20 & 3,25 & 3,30 & 3,20 \\
Rasa & 3,70 & 3,50 & 3,30 & 3,00 \\
Keempukan & 2,75 & 2,90 & 2,85 & 2,70 \\
\hline
\end{tabular}

Hasil uji organoleptik dari dendeng daging ayam dengan pemberian jus daun sirih menunjukkan bahwa nilai organoleptik dendeng daging ayam dengan rataan berkisar 2,7-3,7 (agak suka/suka), warna 3,0-3,1 (suka), aroma 3,2-3,3 (suka), rasa 3,0-3,7 (suka/sangat suka) dan keempukan 2,7-2,9 (agak suka). Rataan nilai organoleptik menunjukkan bahwa semua kriteria memiliki nilai yang berbeda (agak suka/sangat suka).

pada perlakuan 15 persen jus daun sirih tingkat kesukaan panelis terhadap aroma lebih tinggi dibandingkan pada perlakuan 0 persen, 10 persen dan 20 persen, diduga ada senyawa aromatik berasal dari daun sirih, dimana semakin tinggi persentase jus daun sirih pada dendeng maka aroma yang ditimbulkan semakin kuat.

Daun sirih beraroma ini disebabkan ada senyawa kavikol merupakan bersifat volatile dan ciri khas daun sirih dan (mudah menguap) (Indriastuti et al., 2012). Aroma dendeng hasil penelitian dengan pemberian jus daun sirih ini sejalan hasil penelitian Jariyah dan Susiloningsih (2006), dendeng dimana beraroma sangat kuat dengan bertambahnya konsentrasi jus daun sirih diberikan dan bertambahnya waktu penyimpanan maka aroma daun sirih akan menurun. Menurut (Winarno, 1995) 
aroma merupakan dapat menarik perhatian konsumen, aroma yang enak kemungkinan besar mempunyai rasa yang enak sehingga konsumen cenderung menyukai makanan dari aromanya.

\section{Pengujian Total Mikroba}

Tabel 2 menunjukkan rataan total mikroba yang tinggi terdapat pada perlakuan 0 persen jus

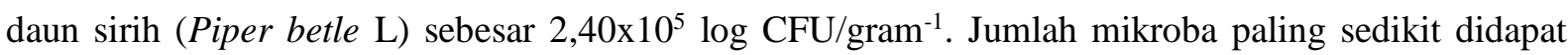
pada perlakuan 20 persen jus daun sirih yaitu sebesar $0,20 \times 10^{5} \log \mathrm{CFU}_{\text {gram }}{ }^{-1}$. Makin tinggi persentase jus daun sirih diberikan dendeng disebabkan semakin terhambat pertumbuhan. Penelitian ini menunjukkan pada pemberian sangat efektif dalam jus daun sirih dapat menghambat pertumbuhan bakteri pada dendeng daging. Hasil penelitian total mikroba dendeng daging ayam menunjukkan batasan cemaran bakteri sedikit lebih tinggi dari ketetapan SNI yaitu 1,10x10 $\log$ CFU/gram ${ }^{-1}$, sedangkan menurut SNI batasan cemaran maksimum cemaran mikroba dalam pangan yaitu $1 \times 10^{5} \log$ CFU/gram ${ }^{-1}$.

Tabel 2. Total Mikroba Dendeng Daging Ayam $\left(10^{5}\right)$

\begin{tabular}{cc}
\hline Jus Daun Sirih (\%) & TPC $\left(\mathbf{1 0}^{\mathbf{5}}\right) \mathbf{( C F U / g r )}$ \\
\hline 0 & 2,40 \\
10 & 1,10 \\
15 & 0,40 \\
20 & 0,20 \\
\hline Berbeda terdapat pada ${ }^{\mathrm{a}, \mathrm{b}}$ Superskrip kolom dengan sama menunjukkan perbedaan sangat nyata \\
$(\mathrm{P}<0,01)$
\end{tabular}

Hal ini diduga karenakan senyawa kavikol yang terdapat pada daun sirih bersifat bakterisidal dalam menghambat pertumbuhan bakteri. Penelitian ini sejalan dengan pendapat Jariyah dan,Susiloningsih (2006) sirih bahwa terngandung minyak atsiri terdapat dalam senyawa fenol dan kavikol, yaitu bahan mempunyai peranan dalam menghambat pertumbuhan bakteri pembusuk. Ditambahkan Harapini et al. (1996) Daun sirih hijau mengadung minyak atsiri senyawa fenol dengan turunannya yang mampu denaturasi sel bakteri protein sehingga pertumbuhannya terhambat.

\section{KESIMPULAN DAN SARAN}

Dendeng daging ayam menggunakan jus daun sirih (piper betle L) sampai 10 persen secara keseluruhan dinilai dari tingkat kesukaan panelis melalui uji organoleptik menujukkan nilai agak suka hingga suka. Sedangkan untuk total mikroba menunjukkan bahwa total mikroba pada 10 persen jus daun sirih sedikit lebih tinggi yaitu $1,10 \times 10^{5} \mathrm{CFU} /$ gram dari batasan maksimum cemaran bakteri yang ditetapkan Standar Nasional Indonesia (SNI 01-7388-2009) terhadap produk olahan daging yaitu $1 \times 10^{5}$

\section{DAFTAR PUSTAKA (format yang dipergunakan APA \& Hardvard)}

Bintoro, P., J. Morita., K. Mikawa dan T. Yasui. 2008. Chemical and microbiological analyses of an Indonesia dried beef (dendeng sapi). Journal Hokkaido. 3(63): 287-292.

Esti dan A. Sediadi. 2000. Dendeng ikan. Deputi Menristek Bidang Pendayagunaan dan Pemansyarakatan Ilmu dan Teknologi, Jakarta. http://www.warintek.ristek.go.id. Diakses tanggal: 25 November 2017.

Fachruddin, L. 1997. Membuat aneka dendeng. Kanisius, Yogyakarta. 
Harapini, M., A. Agusta dan R.D. Rahayu. 1996. Analisis komponen kimia minyak atsiri dari dua macam sirih (Daun kuning dan hijau). Prosiding Simposium. Nasional I Tumbuhan Obat dan Aromatika, Bogor.

Indriastuti, A.T.D., Setiyono dan Y. Erwanto. 2012. Pengaruh jus daun sirih (Piper betle L) sebagai bahan pracuring terhadap kualitas mikrobiologi dan sensoris dendeng ayam petelur selama penyimpanan. Agrinimal. 2(2): 65-70.

Jariyah dan Susiloningsih. 2006. Pengaruh perendaman daging ayam dalam jus daun sirih terhadap daya simpan dendeng ayam. Jurnal Protein. 13(2): 154-160.

Kristanti, J.A. 2008. Karakteristik fisik dan organoleptik dendeng ayam layer afkir pada perbedaan metode pembuatan dan pengeringan. Skripsi. Fakultas Peternakan. Universitas Gadjah Mada, Yogyakarta.

Legowo, A.M., Soepardi., R. Miranda., Y. Anisa dan Rohidayah. 2002. Pengaruh perendaman daging pra kyuring dalam jus daun sirih terhadap ketengikan dan sifat organoleptik dendeng sapi selama penyimpanan. Jurnal Teknologi dan Industri Pangan. 12(2): 64-69.

Margono, T., D. Suryati dan S. Hartinah. 2000. Paduan teknologi pangan. Pusat Informasi Wanita Dalam Pembagunan. PDII- LIPI

Standar Nasional Indonesia. 1992. SNI 01-2908-1992. Dendeng Sapi. Badan Standarisasi Nasional, Jakarta

Jariyah dan Susiloningsih. 2006. Pengaruh perendaman daging ayam dalam jus daun sirih terhadap daya simpan dendeng ayam. Jurnal Protein. 13(2): 154-160.

Steel, R.G.D dan J.H. Torrie. 1993. Prinsip dan Prosedur Statistik. Terjemahan: B. Sumantri. Gramedia Pustaka. Jakarta.

Suradi, K. 2009. Karakteristik dendeng ayam broiler pada berbagai suhu dan lama pengeringan. Skripsi. Fakultas Peternakan. Universitas Padjadjaran. Bandung 